\title{
Is 'Nudge' as Good as 'We Think' in Designing Against Crime? - Contrasting Paternalistic and Fraternalistic Approaches to Design for Behaviour Change
}

\author{
By Lorraine Gamman and Adam Thorpe
}

Keywords: behaviour change, situational crime prevention, socially responsive design, participatory design, reframing, social innovation, appreciative enquiry, nudge design

\begin{abstract}
This paper describes a collaborative design led approach to behaviour change developed in the context of design against crime. It compares this collaborative 'we think' way of working to that of 'nudge' design and argues that the participatory design led approach delivers a 'fraternal' rather than 'paternal' strategy for behaviour change that is transformative in its means as well as its ends. We outline situational crime prevention (SCP) and other approaches to modifying behaviour to explain how socially responsive design against crime draws upon SCP as well as a participatory, asset oriented design approach to deliver interventions that reduce opportunities for crime. We introduce case studies from the Design Against Crime Research Centre (Bikeoff and ATM Art Mats) to draw attention to two examples of social design that provide exceptions to the idea (summarized by Niedderer et al 2041) that designers adopt anecdotal approaches rather than meticulous analysis. Finally, we suggest that 'bottom up' participatory strategies associated with socially responsive design may deliver more democratic social transformations, than behaviour change "nudges".
\end{abstract}

\section{Design for Behaviour Change and Design Against Crime}

In the UK in 2015, 45\% of adults who were sent to prison did not change their law breaking behaviour and were reconvicted within one year of release (See Prison Reform Trust 2015 who report that this figure rises to 58\% for those adults serving sentences of under 12 months). Whilst the design of prisons and their experience of it may deliver short term conformity amongst inmates, it fails to deliver long term transformation of criminal behaviours for almost half of those that experience it. This may not be surprising given the tangle of difficulties facing ex-offenders as returning citizens on release, including addiction, employment, skills, housing, health, debt and relationship issues, all of which may challenge their emotional stability, decision making and mental health. Thus, 'correction' of 
criminal behaviours through prison is effective less than half of the time, and alternative approaches are urgently needed - prevention rather than cure.

Design Against Crime (DAC) offers a different approach to crime prevention and behaviour change. Like other forms of health and safety design, DAC seeks to find new ways to modify the environment in which routine "accidents" (or in this context "crimes") take place. Anticipating and designing against actions before they happen, so that they are prevented. It aims to achieve this by attempting to inhibit, deter or thwart criminal behaviours or, alternatively, to generate new types of behavioral responses that exclude crime. In short, design against crime considers opportunities for use, misuse and abuse of products, environments and services to reduce criminogenic affordances (i.e. those which allow or promote crime) and thus reduce the likelihood of crime.

DAC draws on a number of approaches to modify behaviours and design out crime. Crime Prevention through Environmental Design (CPTED) originates from the writings of Oscar Newman (1972), C. Ray Jeffrey (1971) and Jane Jacobs (1961). Since then CPTED theory and practice has been updated by many authors including Armitage (2013), Knights et al (2002), Cozens (2005), Kitchen (2007), Monchuk (2009), and Ekblom (2011) to develop rules and procedures about management of physical space that aim to harden targets, manage or control access, increase surveillance and guardianship, promote maintenance and support social activity in the built environment to reduce crime and anti-social behaviour. DAC's approach also draws on Situational Crime Prevention (SCP) first outlined by Clarke (1983), which has been more successful in developing principles for behaviour change than CPTED. SCP draws on rational choice theory, routine activity theory, and crime pattern theory (Clarke and Felson, 1993; Felson, 1994) that consider the offenders' ability to weigh up the risks and rewards of a given situation and the conjunction of key characteristics necessary for crime to occur. In doing So SCP addresses more than design for the built environment and has, led by Clarke (1997), produced rigorous evaluation of its effectiveness. SCP has consequently been applied to reduce many kinds of crimes, including robbery, burglary, shoplifting and vandalism. These principles and how to apply them in specific situational contexts have informed many problem specific guides to help police, produced by the Centre for Problem Oriented Policing (2016a). SCP is proven as a systematic approach to crime reduction, linked to the manipulation of the objects and systems of consumer society and their impact on behaviour. It is an approach that has informed crime prevention for almost 35 years. It acknowledges that crime happens and that some objects are 'criminogenic', contributing to the likelihood of criminal outcomes. Following this logic, designing out criminogenic objects reduces opportunities for crime as explained again recently by Clarke R. and Newman G. $(1997,2013)$ and Ekblom P. (2012). Clarke's SCP techniques have grown from 12 in 1992 to 25 today (see Table 1 below, Centre for Problem Orientated 
Policing 2016b) and are fairly self explanatory. They include overt physical and psychological 'prompts' that increase the effort and risk involved in crime and remove the rewards, provocations and excuses that allow crime and criminals to be effective, thus impacting on criminal behaviours. These techniques have been widely and internationally adopted by police to manage behaviour in order to prevent crime. 
Table 1: Twenty-Five Situational Crime Prevention Techniques. This chart started in 1992 with 12 techniques and has grown over the years.

Source: Centre for Problem Oriented Policing (2016b)

\begin{tabular}{|c|c|c|c|c|}
\hline Increase the Effort & $\begin{array}{l}\text { Increase } \\
\text { the Risks }\end{array}$ & $\begin{array}{l}\text { Reduce } \\
\text { the Rewards }\end{array}$ & $\begin{array}{l}\text { Reduce } \\
\text { Provocations }\end{array}$ & $\begin{array}{l}\text { Remove } \\
\text { Excuses }\end{array}$ \\
\hline $\begin{array}{l}\text { 1. Harden targets } \\
\text { - Steering column } \\
\text { locks and } \\
\text { immobilizers } \\
\text { - Anti-robbery } \\
\text { screens } \\
\text { - Tamper-proof } \\
\text { Packaging }\end{array}$ & $\begin{array}{l}\text { 6. Extend guardianship } \\
\text { - Take routine } \\
\text { precautions: go out } \\
\text { in group at night, } \\
\text { leave signs of } \\
\text { occupancy, carry } \\
\text { phone } \\
\text { - "Cocoon" } \\
\text { neighborhood watch }\end{array}$ & $\begin{array}{l}\text { 11. Conceal targets } \\
\text { - Off-street parking } \\
\text { - } \quad \text { Gender-neutral } \\
\text { phone directories } \\
\text { - Unmarked bullion } \\
\text { trucks }\end{array}$ & $\begin{array}{l}\text { 16. Reduce frustrations } \\
\text { and stress } \\
\text { - Efficient queues and } \\
\text { polite service } \\
\text { - Expanded seating } \\
\text { - Soothing music/ } \\
\text { muted lights }\end{array}$ & $\begin{array}{ll}\text { 21. Set rules } \\
\text { - } \text { Rental agreements } \\
\text { - Harassment codes } \\
\text { - } \text { Hotel registration }\end{array}$ \\
\hline $\begin{array}{l}\text { 2. Control access to } \\
\text { facilities } \\
\text { - Entry phones } \\
\text { - } \text { Electronic card } \\
\text { access } \\
\text { - } \text { Baggage } \\
\text { screening }\end{array}$ & $\begin{array}{l}\text { 7. Assist natural } \\
\text { surveillance } \\
\text { - } \quad \text { Improved street } \\
\text { lighting } \\
\text { - } \quad \text { Defensible space } \\
\text { design } \\
\text { - } \quad \text { Support } \\
\text { whistleblowers }\end{array}$ & $\begin{array}{l}\text { 12. } \text { Remove targets } \\
\text { - } \text { Removable car } \\
\text { radio } \\
\text { - } \text { Women's refuges } \\
\text { - } \text { Pre-paid cards for } \\
\text { pay phones }\end{array}$ & $\begin{array}{l}\text { 17. Avoid disputes } \\
\text { - Separate enclosures } \\
\text { for rival soccer fans } \\
\text { - Reduce crowding in } \\
\text { pubs } \\
\text { - Fixed cab fare }\end{array}$ & $\begin{array}{l}\text { 22. Post instructions } \\
\text { - "No Parking" } \\
\text { - "Private Property" } \\
\text { - "Extinguish camp } \\
\text { fires" }\end{array}$ \\
\hline $\begin{array}{l}\text { 3. Screen exits } \\
\text { - Ticket needed for } \\
\text { exit }\end{array}$ & $\begin{array}{l}\text { 8. Reduce anonymity } \\
\text { - Taxi driver IDs } \\
\text { - "How's my driving?" }\end{array}$ & $\begin{array}{l}\text { 13. Identify property } \\
\text { - } \text { Property } \\
\text { marking }\end{array}$ & $\begin{array}{l}\text { 18. Reduce emotional } \\
\text { arousal } \\
\text { - Controls on violent }\end{array}$ & $\begin{array}{l}\text { 23. Alert conscience } \\
\text { - Roadside speed } \\
\text { display boards }\end{array}$ \\
\hline
\end{tabular}




\begin{tabular}{|c|c|c|c|c|}
\hline $\begin{array}{ll}\text { - } & \text { Export documents } \\
\text { - } & \text { Electronic } \\
& \text { merchandise tags }\end{array}$ & $\begin{array}{l}\text { decals } \\
\text { - School uniforms }\end{array}$ & $\begin{array}{l}\text { Vehicle licensing } \\
\text { and parts } \\
\text { marking } \\
\text { - Cattle branding }\end{array}$ & $\begin{array}{ll} & \text { pornography } \\
\text { - } & \text { Enforce good } \\
\text { behavior on soccer } \\
\text { field } \\
\text { - } & \text { Prohibit racial slurs }\end{array}$ & $\begin{array}{l}\text { - Signatures for } \\
\text { customs } \\
\text { declarations } \\
\text { - } \begin{array}{l}\text { "Shoplifting is } \\
\text { stealing" }\end{array}\end{array}$ \\
\hline $\begin{array}{l}\text { 4. Deflect offenders } \\
\text { - Street closures } \\
\text { - Separate } \\
\text { Bathrooms for } \\
\text { women } \\
\text { - Disperse pubs }\end{array}$ & $\begin{array}{l}\text { 9. Utilize place } \\
\text { managers } \\
\text { - CCTV for } \\
\text { doubledeck buses } \\
\text { - Two clerks for } \\
\text { convenience stores } \\
\text { - Reward vigilance }\end{array}$ & $\begin{array}{l}\text { 14. Disrupt markets } \\
\text { - } \text { Monitor pawn } \\
\text { shops } \\
\text { - Controls on } \\
\text { classified ads. } \\
\text { - License street } \\
\text { vendors }\end{array}$ & $\begin{array}{l}\text { 19. Neutralize peer } \\
\text { pressure } \\
\text { - "Idiots drink and } \\
\text { drive" } \\
\text { - "It's OK to say No" } \\
\text { - Disperse } \\
\text { troublemakers at } \\
\text { schools }\end{array}$ & $\begin{array}{l}\text { 24. Assist compliance } \\
\text { - Easy library } \\
\text { checkout } \\
\text { - Public lavatories } \\
\text { - Litter bins }\end{array}$ \\
\hline $\begin{array}{l}\text { 5. Control tools/ } \\
\text { weapons } \\
\text { - "Smart" guns } \\
\text { - Disabling stolen } \\
\text { cell phones } \\
\text { - } \quad \text { Restrict spray } \\
\text { paint sales to } \\
\text { juveniles }\end{array}$ & $\begin{array}{l}\text { 10. Strengthen formal } \\
\text { surveillance } \\
\text { - } \quad \text { Red light cameras } \\
\text { - } \quad \text { Burglar alarms } \\
\text { - } \quad \text { Security guards }\end{array}$ & $\begin{array}{l}\text { 15. Deny benefits } \\
\text { - Ink merchandise } \\
\text { tags } \\
\text { - Graffiti cleaning } \\
\text { - Speed humps }\end{array}$ & $\begin{array}{l}\text { 20. Discourage imitation } \\
\text { - } \text { Rapid repair of } \\
\text { vandalism } \\
\text { - } \text { V-chips in TVs } \\
\text { - } \text { Censor details of } \\
\text { modus operandi }\end{array}$ & $\begin{array}{l}\text { 25. Control drugs and } \\
\text { alcohol } \\
\text { - Breathalyzers in } \\
\text { pubs } \\
\text { - Server } \\
\text { intervention } \\
\text { - Alcohol-free } \\
\text { Events }\end{array}$ \\
\hline
\end{tabular}


More recently, Lockton et al 2010a and 2010b and Tromp et al 2011 have described four basic principles for design for behaviour change that appear to replicate the principles applied with Clarke's 'situational techniques' (Clarke, 199 2and 2016b) applying a descriptive language, more familiar to design (Table 2).

Table 2: Four Tenets Central to Design for Behavior Change

\begin{tabular}{|c|l|l|}
\hline 1. & $\begin{array}{l}\text { Lockton et al 2010, Tromp et al 2011 } \\
\text { advocate making (crime) } \\
\text { preventative behaviours easier to } \\
\text { engage with. }\end{array}$ & $\begin{array}{l}\text { Clarke 1992 describes: assisting } \\
\text { compliance with rules. }\end{array}$ \\
\hline 2. & $\begin{array}{l}\text { Lockton et al 2010, Tromp et al 2011 } \\
\text { advocate making an undesired } \\
\text { [criminal] behaviour harder to } \\
\text { perform - which may inhibit some } \\
\text { further behaviour or have } \\
\text { concomitant effects, but not } \\
\text { always. }\end{array}$ & $\begin{array}{l}\text { Clarke 1992 describes: } \\
\text { increasing the effort of criminals. }\end{array}$ \\
\hline 3. & $\begin{array}{l}\text { Lockton et al 2010, Tromp et al 2011 } \\
\text { persuading anti crime users to } \\
\text { adopt or want to perform a } \\
\text { particular behaviour [that leads to } \\
\text { increased security] }\end{array}$ & $\begin{array}{l}\text { Clarke's model includes } \\
\text { reducing "provocations" for } \\
\text { criminals and "removing } \\
\text { excuses" e.g. alerting } \\
\text { conscience. Also, reducing } \\
\text { "rewards" }\end{array}$ \\
\hline 4. & $\begin{array}{l}\text { Lockton et al 2010, Tromp et al 2011 } \\
\text { trying to decrease users' } \\
\text { inclination to perform a particular } \\
\text { behaviour (that leads to risk of } \\
\text { crime) or an offender's inclination } \\
\text { to attempt a crime }\end{array}$ & $\begin{array}{l}\text { Clarke's model includes } \\
\text { removing "provocations" and for } \\
\text { both users and criminals. Also, } \\
\text { removing rewards and } \\
\text { increasing the risks and the } \\
\text { effort for criminals }\end{array}$ \\
\hline
\end{tabular}

Behaviour change interventions are complex when linked to design against crime: understanding the causality between crime situations, human behaviours and criminal outcomes; hypothesising how design interventions might disrupt this causality; designing interventions that test the hypothesis besides indicators and methods for measuring their impact; implementing the interventions and methods; collecting relevant data linked to the indicators; and reviewing the (typically empirical) data to determine whether the hypothesis was correct. The number of variables and interdependencies in a given crime scenario suggests many different points and strategies for intervention. This complexity is addressed in Paul Ekblom's frameworks, including the Conjunction of Criminal Opportunity (2010) (which integrates all the SCP approaches and more). Also, his work with Martin Gill on crime scripts (2015) that describes a criminal's view 
of crime processes so as to facilitate identification of the most effective intervention points. These 'conjunctions of opportunity', and the scripts that describe the dynamics and roles of actors within them, must be understood for behaviour change interventions to be appropriately measured and evaluated. This is usually linked to understanding the significance of the criminal behaviours being promoted or and the changes to the crime situation "before" and "after" an intervention is made, typically measured in relation to crime statistics.

In their work, the Design Against Crime team not only draw upon ideas associated with CPTED and SCP, as outlined, but also engage with design approaches that structure the application of design methods and tools to identify the exact interactions and conditions (people, places, objects, environments) in which crimes occur. For example, the team engages with an extended version of the Design Council's (2005) 'Double Diamond' design process, to review wider questions about the crime problems addressed and how they might be tackled in user- friendly ways. This process moves through seven phases of design research activity including Scope, Discover, Define, Develop, Deliver, Measure, Evaluate, Scale/Disseminate (Design Against Crime Centre 2016) to:

- understand the actors involved in the issue being studied, their role and agendas in relation to the issue, and the wider system or process in which the issue occurs (scope).

- understand scenarios and stages of the system or crime process to discover more about the people, places and interactions involved, applying design research methods and tools to do so.

- work with the involved actors, drawing on the aforementioned crime frameworks, to make decisions to define what the key challenges are, the affordances and interactions that frame their occurrence, the specific objectives of the intervention to be designed, and the indicators that will help to understand whether the intervention is effective in meeting these objectives. The definition of objectives is informed by understandings about the complexity of crime processes, as are the interventions seeking to disrupt them.

- Objectives are described as either 'ultimate' or 'intermediate'. An 'ultimate objective' might be the reduction of a certain crime type, as indicated by reported crime figures, whilst an 'intermediate objective' might be the reduction of a certain behavior known to make that crime more likely to happen or succeed. For example, reducing bike theft by increasing secure locking practices or reducing ATM crime by increasing the distance between ATM users and other users of the streetscape. Such approaches are comparable with those found in public health initiatives (House of Lords Behaviour Change Report, 2012). For example to achieve the ultimate objective of reductions in cases of lung cancer, initiatives might pursue the intermediate objective of reducing the number of smokers. 
- Having defined the intervention opportunity and the indicators that will tell if your intervention is effective, the intervention itself and the method of testing it are developed. This is often an iterative process of prototyping and qualitative testing with relevant actors (those that might 'use' the intervention, but also those that might variously interact with or influence it ['misusers', 'abusers', 'influencers'], thereby impacting its effectiveness).

- Having developed an apparently appropriate and effective intervention one might work with stakeholders to implement a "controlled" trial to measure and evaluate whether or not the intervention can be evidenced as effective and should therefore be implemented more widely.

When designing for behaviour change, clear identification and articulation of the process, from researching the intervention opportunity to designing the evaluation, ensures that others can build upon, replicate and retest effective practice. The Design Against Crime Research Centre is cautious not to advocate a "one size fits all" approach, given the significance of contextual and cultural differences. Appreciation of the 'socially situated' nature of crime and design (Suchman,1987) has lead the team to consider crime problems not just in terms of the behaviours and practices requiring address to reduce crime, but also the relationship between the incidence and impacts of crime and other social behaviours and practices. In short, given that the built environment and public space is experienced by the law-abiding majority, the team seeks to locate DAC as a socially responsive design approach, that combines design against what we want less of (crime and anti-social behaviours) with design for what we want more of (pro-social behaviours). This positivist focus of socially responsive DAC focuses on amplification of positive possibilities rather than solely focusing on the prevention of negative outcomes. In doing so it has an affinity with "appreciative enquiry", outlined by Cooperrider and Srivastva (1987), which suggests that excessive focus on problems or dysfunctions can actually cause them to become worse or fail to become better.

\section{Design Against Crime Case Studies}

The work of the Design Against Crime Centre and the iterative and collaborative design process we have developed and applied, has contributed to a national Design Council/Home Office 'Design Out Crime' initiative (Design Council 200810) delivered in response to government targets for crime reduction; it is explained in detail elsewhere (see Thorpe and Gamman et al, 2010; Gamman and Thorpe, 2011; Thorpe, 2013; Thorpe and Gamman, 2015). The case studies below illustrate this approach and explain how collaborative processes contribute 
to behavior change, as well as how the outputs from these processes are used.

\subsection{Bikeoff (2004-2011)}

The Bikeoff research initiative was created by the Design Against Crime Research Centre over ten years ago as a response to cycle theft experienced by staff and students at Central Saint Martins, an art and design college in London. Bikeoff worked with a broad community of individuals and organisations concerned with cycling, crime and design, aiming to activate "a design revolution" to reduce cycle theft and increase cycle use (Thorpe et al, 2010). Central to the initiative was collaboration between researchers at the Design Against Crime Research Centre and the UCL Jill Dando Institute of Crime Science, supported by research funding from the AHRC/ EPSRC Designing for the 21st Century programme.

The initiative produced design guidance, design resources and design exemplars (products, communication strategies, services and environments) targeted at reducing opportunities for bike theft. Specific outputs included a range of antitheft bike stands, one of which, the caMden stand (Fig. 2) is now specified by Transport for London and installed on the streets of London. The caMden stand design is the result of ethnographic research into bike theft perpetrator techniques and extensive observation of bicycle parking practices at sites in central London. This knowledge of bicycle theft techniques and cycle parking behaviours informed the design of bike stands that reduce the opportunities for insecure locking practice, particularly the securing of bikes to the stand using only the top tube of the bike frame. Key to the design response was an understanding of which locking behaviours are more secure, and therefore to be facilitated by the design, and which are less secure and therefore to be prevented. There are 180 ways of securing a typical diamond framed two-wheeled bicycle $(75 \%$ of observed parked bicycles) to a standard n-shaped 'Sheffield' stand, using two locks. These ways of locking can be divided into three groups, namely:

- Good - both wheels and the frame locked to the stand,

- OK - one wheel and the frame locked to the stand, and

- Bad - either one wheel or the frame (or neither) locked to the stand

By observing and recording the locking behaviours of cyclists using the new stand designs e.g. how many locked their bikes to the stand in "Bad", "OK" or "Good" ways, we were able to compare these figures with those for cyclists locking to a standard n-shaped 'Sheffield' stand design and establish which of the stands promoted the most secure locking practices.

The caMden stand design 'nudges' cyclists to lock both the wheel and the frame of their bike to the stand by making it harder for them to lock the crossbar alone (a common insecure bicycle locking practice identified by the research). By 
encouraging cyclists to lock both the frame and the wheel to the stand it makes it harder for thieves to steal the bike using common theft techniques. The 'effectiveness' of the CaMden stand, in terms of promoting secure locking practice, was tested in control trials evaluated by the Jill Dando Institute of Crime Science (Thorpe et al, 2012). Cyclists were found to be more likely to lock securely to the new stand designs - a key intermediate outcome for reducing opportunities for theft.

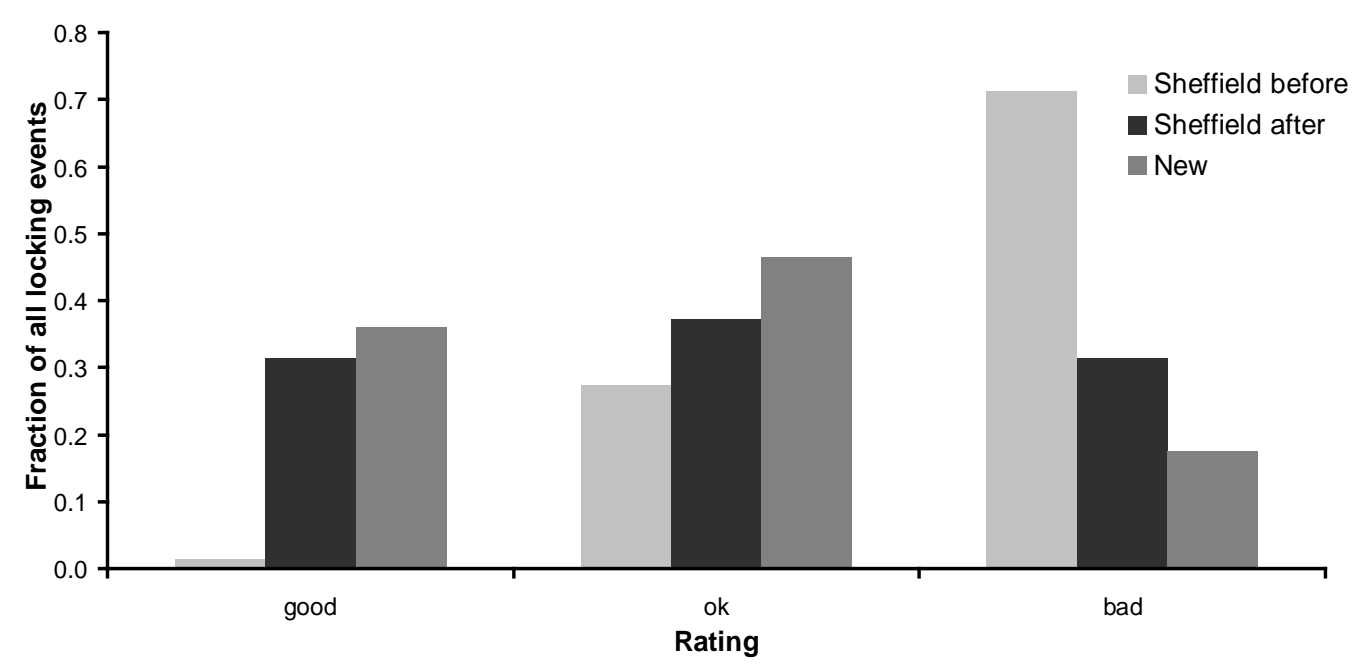

Fig. 1: Locking Practices for Sheffield Stands versus the Prototype Bicycle Parking Stands as a Single Group

Fig. 2: CaMden stand

Source: Design Against Crime Research Centre, 2007

Despite the quantitatively substantiated success of the caMden stand as a design nudge, what the above graphs do not explain, is the cultural impact of the collaborative process of designing the caMden stand. Several different secure cycle stand designs where iteratively developed with the involvement of police, cycle furniture manufacturers, cyclists, and cycling experts and advocates from Transport for London's Cycling Centre for Excellence and London Cycling Campaign. Whilst these collaborative design activities delivered the " $\mathrm{M}$ " stand, which was evidenced to make a difference to opportunities for bike theft, the caMden stand design itself constituted just one of many 'design things', defined by Binder et al (2011) as "socio-material assemblies around issues of concern", used by the Bikeoff project to promote greater awareness of cycle theft and more secure behaviours amongst cyclists.

The London Bicycle Film Festival, co-produced by Bikeoff for the first time in 2005, features films that celebrate cycling made by cyclists that share their passions and experiences. A common experience was of cycle theft, and consequently many of the films focused on this subject. As part of the festival 
the Bikeoff initiative used the bike theft-focused film content to support training sessions delivered to police and others concerned with cycle security. We thereby used art and design to introduce the knowledge and experience of cyclists to dutyholders i.e. those paid to address cycle theft prevention. We believe this sort of cultural engagement; plus our co-creation and co-delivery of several national bike crime exhibitions and conferences that identified best practice in reducing bike theft, created new cultural knowledge that was previously absent. In doing so the 'petty crime' of cycle theft was recognized as more significant, informing changes to national policies in street management and policing in addition to market demand for the caMden stand designs. Geoffrey Crossick and Patriycia Kaszynska, in their 2016 report for the AHRC, recognize such creative cultural interventions as significant in that they "provide the space in which disruption to established ways of thinking might safely take place". Through cultural engagement and collaborative creative practice we introduced many diverse voices and perspectives to the discussion, that demanded change and influenced design debate. Such activities enabled us to move beyond SCP or nudge techniques, mainly concerned with the design of choices, which influence the decisions we make. Nudge theory, associated with Thaler and Sunstein (2008) proposes that the designing of choices should be based on how people actually think and decide (instinctively and rather irrationally), rather than how leaders and authorities traditionally (and often incorrectly) believe people think and decide (i.e. logically and rationally). The design of "choice architecture," aims to achieve changes in people's behaviours by influencing their choices through design, rather than relying on informed consent and traditional methods of direct instruction, enforcement or punishment. Conversely, participatory design mobilises a collective approach to informed consent, the articulation of concerns and the review of proposals that might change behaviours to reduce cycle theft. We consider all this socially responsive and collaborative activity and engagement with cycling groups, police and government agencies, as well as designers and design students, and later the Design Council and Home Office, to be our most important design contribution. It helped build informed awareness around the issue of cycle theft, beyond the nudging of the stands users. No wonder the " $\mathrm{M}$ " stand was wellreceived when launched and despite initial skepticism, participation encouraged many cyclists to carry two locks. This may also be because, for a period, we helped raise the salience of bike theft in key stakeholder minds. We targeted the police in the UK who, certainly influenced by Bikeoff's 'thinging', and so changed bike theft to be a 'comparator crime' ${ }^{1}$. Consequently, during this period bike theft in London diminished whilst cycling increased (Fig. 3).

Fig. 3: Graph by Rose Ades from presentation 'Putting the Brakes on Bike Theft', London Bicycle Film Festival, Barbican, 2008.

${ }^{1} \mathrm{~A}$ comparator crime is a crime type against which police performance is measured by the Home Office. 
Source: Conference proceedings 'Putting the Brakes on Bike Theft', London Bicycle Film Festival, Barbican, 2008.

The above explains how Bikeoff operated in a collaborative and 'fraternalistic'2 way to influence cultural values. The project provided a space where knowledge was exchanged, transferred and co-produced and understandings between stakeholders and dutyholders shared. Participatory design methods, including seeking feedback on design prototypes, democratised access and facilitated input to discussions and decisions around cycle security (including design decisions). This helped ensure the designs and communications against bike theft were as contextually-appropriate as possible. The involvement of stakeholders in ideation and decision-making processes also engendered ownership amongst stakeholders that supported adoption and implementation by them, furthering the possibility of behaviour change. The contribution of physical prototyping of proposed solutions to the consideration and resolution of shared problems is understood amongst design practitioners for whom prototyping has long been a way of exploring possibilities and supporting decision-making. The appreciation that 'making things makes things happen', and the conception of the prototype object as a site for cultural debate and exchange is well articulated by design theorists. Bill et al (2015) state that "prototypes are not simply evolving objects, or 'objects-to-be'. The processes by which ideas are refined and tested through prototyping have much wider social significance" and with Murray et al (2010) we argue that "it's through iteration, and trial and error, that coalitions gather strength (for example, linking users to professionals) and conflicts are resolved (including battles with entrenched interests)."

The 'designing coalition' (Manzini, 2015) that the Bikeoff initiative assembled via the activities described above, co-produced a new way of understanding and problematising bike theft, and gave the issue greater significance amongst stakeholders and dutyholders in the process.

Considering the behavioural impact of the co-design of the CaMden stand, and the interactions and iterations that contributed to its creation, what was prototyped was both:

(i) a new way of using (the co-articulation amongst stakeholders of a more secure way of locking a bike - a new behavior),

(ii) a new object of use (the bike stand that made this new behaviour easier and more intuitive than other, less secure, ways of locking),

(iii) changed cultural values about bike theft - when we put on Reinventing

\footnotetext{
${ }^{2}$ We use the term fraternalistic as an alternative to paternalistic - not to denote a gendered account of brotherhood but rather a comradely and co-operative relational interaction) e.g. 'denoting an organisation for people, especially men, that have common interests or beliefs: a network of political clubs and/or fraternal organizations' http://oxforddictionaries.com/definition/fraternal. Downloaded 1.9.2015.
} 
the Bike Shed, the first bike design exhibition in London led by designers, many other designs and expos that weren't commerciallyfocused, followed...

Thus, the locking behaviours of cyclists were ultimately influenced in the cocreation of the bike stand as well as in its subsequent use. There was an exchange and a negotiation, by which stakeholders and dutyholders contributed to the definition of what we think (Leadbeater 2009) is a more secure way to lock a bike (e.g. climate setting) before there was a nudge delivered by the stand design that favours this way of locking.

Whilst the CaMden stand can be considered as a designed nudge, given its effectiveness at changing the behaviour of cyclists through conscious design activity, we think it is a very different kind of nudge design from the conventional understanding of the term which suggests that "small [design] changes can make a big difference" (Halpern 2015).

The difference lies in the participatory process by which the desirable outcome of the intervention is co-defined and the strategy for achieving it (the nudge) codeveloped. This participatory approach is supported by activities that assemble dutyholders and stakeholders around the issue of concern and foster cultural exchange and debate that, to borrow from Papanek (1995) 'informs' [those involved in the process], 'reforms' [normative perspectives and values in relation to the issue of concern amongst those involved in the process and their networks] and 'gives form' [to the co-designed output - the nudge]. We consider this participatory approach to be more equitable, more democratic and less paternalistic than other approaches to behaviour change by design.

\subsection{ATM Art Mats (2010-2015)}

Fig. 4: ATM Art Mat

Source: Design Against Crime Research Centre, 2010

Between 2008 and 2011, the most common ATM crime perpetrator techniques in City of Westminster, London, were 'distraction theft' (between 63\% and 77\% of reported ATM crime) followed by 'skimmer/reader' or 'trapping' offences (between $4 \%$ and $11 \%$ - as indicated by the fact that cash was later deducted from the victim's account) ${ }^{3}$.

\footnotetext{
${ }^{3}$ Westminster Police Data regarding the modus operandi (MO, or perpetrator technique) used by offenders when committing ATM crime in Westminster (as identified by reading the 'CLASS Method' entry on each of the relevant CRIS records for 3 years between 2009 and 2011).
} 
Much has been done through technological intervention to address some of these techniques. Devices are retrofitted to ATMs to incapacitate card 'skimmers', sense when 'card traps' are inserted or to shield ATM users' PINs from prying eyes. However, interventions aimed at 'distraction theft', 'pickpocketing' and 'shoulder surfing' have been limited to the introduction of 'safety zones' around ATMs. These 'safety zones' typically comprise yellow boxes painted on the pavement to define a 'defensible space' (Newman, 1972) that customers can point to when requesting privacy. They work by increasing the distance between ATM users and other users of the streetscape - including those seeking to steal ATM users' cards or cash. This defensible space prevents common theft techniques such as shoulder surfing, dipping and distraction theft, all of which require thieves to be near their target. Whilst these zones have been reported to be effective in reducing crime in the vicinity of ATMs (Holt \& Spencer, 2005) there is little enthusiasm amongst banks, businesses, place managers or the public for this solution. This may be because the yellow lines are more commonly associated with instructing vehicles and traffic, rather than people, and many consider their appearance detracts from the appeal of our high streets and signals insecurity. In an attempt to find a more appealing solution for defensible space the Design Against Crime Research Centre, working with Hammersmith Police, trialed ATM Art mats at Royal Bank of Scotland (RBS) cash machines in Hammersmith, London in 2010 (see Fig. 4). Anecdotal evidence suggested the ATM Art mats were effective in creating defensible space and well-liked by businesses and the public. As part of a multi-channel approach to ATM security, which includes address to technology, environment and behaviour, RBS ATM Fraud Control commissioned a control trial of ATM Art to test its effectiveness in improving customer security and customer experience at ATMs, so as to build a robust evidence base for any future recommendations regarding installation of ATM Art.

Ten NatWest ATM sites within City of Westminster and London Borough of Camden were selected on the basis of being ATM crime hotspots, experiencing the highest levels of reported ATM crime. Of the ten sites selected eight were paired according to similarities in the number of reported ATM crimes at the site, transaction volumes and situational site characteristics relating to the ATM itself, its immediate vicinity, and the wider environment around the ATM. The remaining two sites, although not suitable for pairing due to unique characteristics, were included in the trial as these experienced the highest levels of reported ATM crime within the study area. Pre-observations (before deployment of the ATM Art) were made between mid May and mid July 2012 and data was recorded relating to the behaviours of ATM users and other users of the streetscapes during ATM transactions. At the start of August 2012, four of the paired sites received ATM Art mats along with the two unpaired sites that experienced highest levels of ATM crime. The four sites that did not have ATM Art mats installed acted as control sites to their pairs. After the installation of the ATM Art mats to six of the sites, 
comparable post-observations were recorded of ATM transactions at all ten sites. Data relating to the behaviours of ATM users and other users of the streetscape, with and without mats present, were analysed and compared.

The results demonstrated that the ATM Art Mats significantly increased the distance between the ATM user and other users of the streetscape by, on average, a further $80 \mathrm{~cm}$ than when no mats were present (Thorpe, 2013). Additionally, the mats were observed to increase the tendency of ATM users to look over their shoulder (a useful defensive behaviour), whilst having no adverse impact on their tendency to cover their PIN (a concern had been that the increase in privacy might result in reductions in PIN covering).

The research evidenced that the ATM Art Mats deliver an effective 'nudge' to streetscape users to 'stand back' when mats are occupied by an ATM user, increasing privacy of ATM users and reducing opportunities for cash, card and PIN theft.

Additionally, a survey into ATM user behaviours, conducted with over 250 ATM users as part of the research, found that nine out of ten ATM users surveyed said that they had, at some time in the past, wanted to request privacy before using an ATM (e.g. by asking another person to step back). However, of those people expressing this desire, only $44 \%$ had actually felt able to make such a request. Thus, whilst the 'nudge' is effective in changing the normative behaviours of people around an ATM, granting more privacy to ATM users, more needs to be done to increase the likelihood of the ATM user to request privacy if the 'nudge' of the ATM Art Mat is ignored by other users of the streetscape (as would likely be the case if a criminal were consciously trying to steal from the ATM user).

To address this concern, a collaborative and participatory approach to the creation of the ATM Art Mat artwork was embarked upon. A series of art workshops were conducted in 2014/15 with schoolchildren living near the Camden ATMs where the artworks were to be installed. The students created artworks to be printed onto the Mats and installed at the local ATMs. The workshops started by explaining to students about the issue of ATM crime that the artworks address. The intention is that once installed, the artworks deliver the 'nudge' to users of the streetscape to 'stand back' but also extend the debate amongst local people around why the artworks are there, how they work, and the role of the ATM user in protecting their own right to privacy. Workshop materials have been produced, along with protocols for implementation, that support bank managers and other stakeholders and dutyholders in implementing ATM Art workshops, and the resulting art mats, as another channel of defence against ATM crime in their local area. This process uses the creation of artworks as a 'thing', a means of public assembly around an issue of concern, to raise awareness for ATM security (and the right to privacy), involving local people to 
afford greater local ownership of, and pride in, the public realm for 'ATM Artists' and their communities as well as expanding understandings about the cultural significance of instrumental art. At the time of writing the new ATM Art Mats are awaiting installation in Spring 2016.

\section{What is the 'nudge' approach to behaviour change and how is it different to 'we think'}

What is 'new' about nudge design is that it often prioritises psychological prompts aimed at directing choices towards actions with positive social outcomes. For example, changing the defaults on organ donation to 'presumed consent' to save lives, or the messaging on tax forms to create cost savings for government, constitute top down nudges.

Nudge logic holds that through subtle changes to the world around us government can subtly change behaviours so that we experience more positive outcomes. These 'nudges' are the result of conscious design decisions that are intended to encourage positive behaviours (Gatsby, 2014). If a nudge is a way of encouraging and guiding behaviour without mandating or instructing, and ideally without the need for heavy financial incentives or sanctions, then clearly its codes and conventions may have a relation to design. Just like the design of roadside signs aimed at guiding traffic to share the road safely are linked to soft emotional prompts, or the design of fruit packaging stored near the till at checkouts are aimed at promoting healthy eating, all these strategies involve psychological cues as well as physical prompts and interaction opportunities.

Strategies that deliver positive behavioural prompts have much in common with Norman's (1988) concept of 'affordance' in design - the idea that the designed appearance of objects communicates a range of action possibilities to their users. Indeed, design has always delivered prompts. What Packard (1957) called 'hidden persuaders' and what Cialdini (2007) calls the 'influence of persuasion', has much in common with what Thaler and Sunstein in their book Nudge (2008) redefine as 'choice architecture'.

The UK's Behavioural Insights Team (BIT) - dubbed the 'Nudge Unit' - has used a wide range of measures to successfully 'nudge' citizens towards decisions and behaviours that will improve their lives or safety and save public money. Interestingly, BIT's approach is typically one of promoting positive outcomes rather than denying negative outcomes. It is often concerned with re-designing written materials to promote positive choices by making preferable outcomes easier to achieve than less desirable outcomes; or reminding people of the positive choices their neighbours make already as a way of encouraging others 
to do the same. Halpern (2015, p.158) links this strategy to principles summarized in the mnemonic 'EAST' summarised in Table 3, which has much in common with the Tables featured in section one generated by Clarke's account of SCP and account of Behaviour change. 
Table 3: ‘EAST’ Principles (Halpern, 2015)

\begin{tabular}{|c|c|c|c|}
\hline & Headline & Things to think about & Examples \\
\hline Easy & $\begin{array}{l}\text { Make it easy. } \\
\text { People are much more } \\
\text { likely to do something if it's } \\
\text { easy and low-hassle }\end{array}$ & $\begin{array}{ll}\text { - } & \text { Simplify } \\
\text { - } & \text { Friction: remove, or add it to inhibit } \\
\text { - } & \text { Defaults: set the easy path as the } \\
& \text { healthiest, safest option }\end{array}$ & $\begin{array}{l}\text { - Pensions: millions more saving as a } \\
\text { result of auto-enrolment } \\
\text { - Suicide: reduced when easy routes } \\
\text { blocked } \\
\text { - University entry: } 25 \text { per cent more } \\
\text { poor students go when forms pre-filled }\end{array}$ \\
\hline Attract & $\begin{array}{l}\text { People are drawn to that } \\
\text { which catches their } \\
\text { attention, and that which is } \\
\text { attractive to them }\end{array}$ & $\begin{array}{l}\text { - Personalize: use recipient's name; } \\
\text { make relevant } \\
\text { - } \quad \text { Salience: make key point stand out } \\
\text { - } \text { Messenger: experts and named } \\
\text { individuals beat anonymous or } \\
\text { distrusted sources } \\
\text { - Lotteries: make incentives more } \\
\text { - } \text { attractive }\end{array}$ & $\begin{array}{l}\text { - Tax: } 10 \text { times more doctors declared } \\
\text { income with salient letter } \\
\text { - Giving: } 2 \text { times more donations to } \\
\text { emergency appeals with story of one } \\
\text { child versus statistics of millions } \\
\text { affected } \\
\text { - Courts: } 3 \text { times more likely to pay } \\
\text { fines with a personalized text }\end{array}$ \\
\hline Social & $\begin{array}{l}\text { People are strongly } \\
\text { influenced by what others } \\
\text { are doing or have done }\end{array}$ & $\begin{array}{l}\text { - Norms: what are others actually } \\
\text { doing } \\
\text { - Networks: a friend or colleague } \\
\text { recommends } \\
\text { - Reciprocity and active commitments: } \\
\text { promises } \\
\text { - Reminders of others: eyes and faces }\end{array}$ & $\begin{array}{l}\text { - Litter: } 8 \text { times more likely to drop flyer } \\
\text { if others already on the ground } \\
\text { - Tax: } 16 \text { per cent more likely to pay if } \\
\text { informed that most people 'pay on } \\
\text { time' } \\
\text { - Giving: } 7 \text { times more likely to give } \\
\text { when learning that a colleague }\end{array}$ \\
\hline
\end{tabular}




\begin{tabular}{|c|c|c|c|}
\hline & & & already gave \\
\hline Timely & $\begin{array}{l}\text { Interventions are more } \\
\text { effective before habits } \\
\text { have formed, or behavior } \\
\text { has been disrupted for } \\
\text { other reasons }\end{array}$ & $\begin{array}{l}\text { - Habit: intervene before they become } \\
\text { established } \\
\text { - Key moments: when behavior is } \\
\text { disrupted } \\
\text { - Priming and anchoring: the power of } \\
\text { what just came before } \\
\text { - Time inconsistency: discounting of } \\
\text { the future }\end{array}$ & $\begin{array}{l}\text { Development: two-thirds more farmers } \\
\text { take up fertilizer offer after harvest } \\
\text { when cash-rich } \\
\text { - Health: } 3 \text { times more workers choose } \\
\text { healthy option a week ahead than one } \\
\text { day } \\
\text { - Tax: } 2 \text { times more less likely to } \\
\text { respond to nudge if late paying } \\
\text { previous year }\end{array}$ \\
\hline
\end{tabular}


BIT works for government and in their 2014-5 report they state: "our objectives remain the same: making public services more cost-effective and easier for citizens to use; improving outcomes by introducing a more realistic model of human behaviour to policy; and wherever possible, enabling people to make "better choices for themselves" (Prime Minister's Office et al, 2010 - restated by Halpern, 2015).

Yet success linked to nudges is not about democratising decisionmaking and enabling people to make 'better choices for themselves'. Instead, nudges help good social outcomes happen by making choices for people about what 'better' looks like, and then discriminating positively for these choices in the design of the interactions. The approach is a 'top down' one that echoes a managerialist and often cost-saving emphasis currently at the heart of current UK public sector decision-making. Yet there is so far no doubt that such small changes are being designed to mobilise behavioural psychology for the greater good. As Halpern (2015, p.121), in his recent book, Inside the Nudge Unit observes:

"Behavioural approaches aren't just about invisible nudges that pull in a bit more tax revenue, or help deliver some worthy but distant outcome. At their best such interventions are about understanding who we are, about connecting and communicating with each other better, about frankly designing services for human beings ..."

Despite this positive emphasis concerns have been raised about the approach as the creation of default settings deliver presumed consent, rather than informed consent. Consequently such an approach may be undemocratic or may mis-use government budgets, leveraging apathy against democracy. As one senior Minister (quoted by Halpern, 2015, p.35) commented the nudge approach is "not quite cricket is it?".

Many of today's societal challenges are 'wicked' (Rittel \& Webber, 1973; Buchanan, 1992; Buchanan and Margolin, 1995) in that they are complex, networked problems with no single origin or owner and multiple, sometimes contradictory, desirable outcomes for the people that experience them. Responses to such wicked challenges benefit from 'open' and collaborative approaches that bring multiple and diverse resources, disciplines and knowledge to bear on a problem. To ensure the engagement of the multiplicity of actors necessary to impact upon these complex networked problems, the process with which they are required to engage must acknowledge and address the multiple and diverse drivers that matter to them, and in that process include a positive focus (in terms of Bikeoff this meant not just less bike theft but the promotion of more cycling). This positive approach, as mentioned earlier, has been described 
elsewhere by Whitney and Trosten-Bloom (2010) as 'appreciative enquiry' 4 aimed at delivering change to organisations. This focus moves beyond problem solving and asks positive questions of the potential of a given person, organisation or situation in order to realise such positive effects as summarised in Table 4.

Table 4

\begin{tabular}{|l|l|}
\hline Problem Solving & Appreciative inquiry \\
\hline $\begin{array}{l}\text { Felt need, identification of } \\
\text { problem(s) }\end{array}$ & $\begin{array}{l}\text { Appreciating - valuing "the best of what } \\
\text { is" }\end{array}$ \\
\hline Analysis of Causes & Envisioning what might be \\
\hline Analysis of possible solutions & $\begin{array}{l}\text { Engaging in dialogue about what should } \\
\text { be }\end{array}$ \\
\hline Action Planning (treatment) & Innovating what will be \\
\hline
\end{tabular}

Source: Cooperrider and Srivastva, 1987

Above we can see an element of what is known as "reframing" involved in appreciative enquiry. Kees Dorst, founder of the Designing Out Crime Research Centre at the University of Technology Sydney that emerged in 2007, has developed and articulated this account of 'reframing' in a clear methodological way (Dorst, 2015). He describes a series of steps supported by a set of design methods and tools that enable groups of actors to identify and articulate their values in order to find new perspectives from which to address previously intractable challenges. Reframing ATM crime as an opportunity for community arts projects is one way of understanding the reframing process.

Further examples include Dorst's own work reframing problems associated with drunkenness and anti-social behaviour linked to the night-time economy of the King's Cross district of Sydney. Instead of persisting in ever harsher policing of these 'problems' in the existing frame of crime and disorder, Dorst and his team suggested that stakeholders 'reframe' the challenge of policing the area to that of managing a 'festival' and design ways to accommodate or deter the anticipated

\footnotetext{
${ }^{4}$ Appreciative enquiry suggests that excessive focus on problem solving "dysfunctions" can actually cause them to become worse or fail to become better. So instead when all members of an organisation are motivated to understand and value the most favourable features of its culture, this is a beter method to make rapid improvements.
} 
behaviours, opening the challenge up to more creative and collaborative responses than might be conceivable or achievable through an antisocial/policing lens.

\section{Conclusion}

In a time of uncertainty, facing complex societal challenges that demand immediate address, it is no surprise that appreciative enquiry and ideas about "reframing": should be finding admirers in those interested in organization change, or that the UK government has created a 'nudge' unit to focus on the positive in order to achieve some necessary 'quick wins' and more generally boost compliance with norms. For example, steering publics' decisions in directions that may improve citizens' health and well being (approaches in Wales that opt everyone into organ donation) whilst also delivering cost savings for government are obviously appealing to those looking for solutions. Thaler \& Sunstein (2008) were early promoters of such paternalistic strategies in book Nudge that outlined behavioural economics as applied to law. As we have explained, the UK's BIT unit have developed the approach, using psychology to deliver change with sophistication, creativity and with real-world effects that should not be undervalued or underestimated, even if these replace informed consent with manipulation that constitutes presumed consent. Our account of design against crime as socially responsive design also seeks urgent address to current complex social challenges, and is similar to appreciative enquiry because it is pro-social in emphasis; but it differs from nudge in that its approach is fundamentally participatory rather than paternalistic. It recognizes that designers cannot ultimately be responsible for the outcomes of the design process and that to be effective and democratic scenarios require collaboration and compromises between stakeholders - a fraternal approach to designing that is responsive to the context in which a design activity is situated, and the people with whom a designer is designing, and involved. So whilst we agree with Tromp et al (2011) that designers can make a difference and "have to take responsibility as "shapers" of society', we acknowledge limits to the designer's influence and role in a context where economic forces and other political influences and drivers still have significant determination on which designs actually reach the world.

BIT's need to create the right conditions for 'nudge' to succeed 5 , we believe is often positive but undemocratic, whereas the participatory approach the Design Against Crime Research Centre advocates, even when drawing upon SCP, is more inclusive and serves to democratize innovation. We seek to harness the

\footnotetext{
${ }^{5} \mathrm{Halpern}$ talks about the need to get right and balance contextual factors before undertaking such interventions such as Administrative support; Political support; People; Location; Experimentation; Scholarship (APPLES).
} 
possibility and potential of diverse perspectives and capacities of people, rather than simply using human psychology to manipulate predicted and uniform behavioural responses from an amorphous public. The difference lies in the participatory process by which the desirable outcome of the intervention is codefined and the strategy for achieving it (the nudge) co-developed.

Putting aside concerns relating to democracy and individual agency, the pragmatist must acknowledge that both strategies work to deliver behaviour change. Nudging is found to be appropriate in situations where we think we know the 'right' answer, where the greater good is obvious to all, in scenarios where no intentionality or agency is required, where the greater good will be served by behaviours that are unconsciously redirected. But, nudging does not work to change behaviours at a conscious level. Nor, does nudging work to bring together stakeholders to work out what the 'right answer' or 'greater good' might be in scenarios where contested understandings and competing objectives might limit the possibility of 'one right answer'.

Whilst improved outcomes resulting from unintentional changes to behaviour are welcomed, especially when it saves lives and saves money, there are certain desirable outcomes that necessitate desirable behaviours that require the conscious intention and decision of the involved actors. For example, asking for more privacy at an ATM or championing cycling, cyclists' safety and cyclists' security in our cities. These complex scenarios require open, inclusive and collaborative processes that foster the assembly of publics around issues of concern so that desirable outcomes can be collaboratively defined, and interventions to achieve them collaboratively designed. The kind of democratized climate-setting and participatory design that DAC actions and advocates is likely to have an impact on behavior that is more strategic, more generalized and more durable (i.e. reach beyond the specific effect of a specific momentary change in behaviour - wording on a tax form, say). But, obviously, harder work to accomplish and with a greater chance, with all those actors involved, that the effects may occur in unexpected directions. So, is 'nudge' as good as 'we think' in design against crime through behaviour change? It depends on context. Both 'nudge' and 'we think' offer different opportunities for impact in pursuit of desirable outcomes for citizens, both in the moment and in the future but denial of informed consent and agency of involved actors in the behavioural choices they make is likely to necessitate constant intervention rather than sustained transformation.

\section{Bibliography}


Armitage, R (2013). Crime Prevention through Housing Design: Policy and Practice . Crime Prevention and Security Management. Basingstoke: Palgrave Macmillan.

Armitage, R. and Monchuk, L. (2009) 'Reconciling security with sustainability: the challenge for Eco-homes." Built Environment, 35 (3). pp. 308-327.

Bill, A., Reay, S. D., and Collier, G. (2015). Making Things Happen: Experiments in Prototyping from a Hospital Design Lab. In: Summer Cumulus Conference, Politicencio Di Milano, 3 - 7 June 2015.

Binder, T. et al A.TELIER (Project) (2011). Design things. Cambridge, Mass: MIT Press.

Buchanan, R. (1992). Wicked Problems in Design Thinking, Design Issues, 8 (2), 5-21.

Buchanan, R. and Margolin, V. (1995). Discovering design-Explorations in design studies. Chicago: The University of Chicago Press.

Centre for Problem-Oriented Policing. (2016a). Guides. University at Albany State University of New York. URL: http://www.popcenter.org/guides/.

Centre for Problem-Oriented Policing. (2016b). Twenty Five Techniques of Situational Prevention. University at Albany - State University of New York. URL: http://www.popcenter.org/25techniques/.

Cialdini, R. B. (2007). Influence: the psychology of persuasion. New York, Collins.

Clarke, R. V. (1983). Situational Crime Prevention: Its Theoretical Basis and Practical Scope. Crime and Justice: An Annual Review of Research, 4, 225-256. Clarke, R. (1992). (Ed.) Situational Crime Prevention: Successful Case Studies. Albany, NY: Harrow and Heston.

Clarke, R. V. and Felson, M. (1993). Routine Activity and Rational Choice. Vol. 5, Advances in Criminology Theory. New Brunswick: Transaction Publishers, Inc.

Clarke, R. (1997). 'Introduction.' In: R. Clarke (ed.), Situational Crime Prevention: Successful Case Studies. Guilderland, NY: Harrow and Heston.

Clarke, R. and Newman, G. (eds) (2013), . Designing out Crime from Products and Systems. Crime Prevention Studies 18. Cullompton: Willan.

Cooperrider, D. L. and Srivastva, S. (1987). Appreciative inquiry in organizational life. In Woodman, R. W. \& Pasmore, W.A. (eds) Research in Organizational Change And Development, Vol. 1 (129-169). Stamford, CT: JAI Press.

Cozens, P. M., Saville, G. and Hillier, D. (2005). "Crime prevention through environmental design (CPTED): a review and modern bibliography", Property Management, Vol. 23 Iss: 5, pp.328 - 356.

Crossick, G. and Kaszynska, P. (2016). Understanding the value of Arts and Culture, The AHRC Cultural Value Projecr Report, 2016. 
Design Against Crime Research Centre. (2009). Methodology. University of the Arts London. See: http://www.designagainstcrime.com/methodologyresources/design-methodology. Sections: Why Users \& Abusers; Resource Mapping; What's at stake?; List \& Description; Why "Open Innovation"; Benefits; References.

Design Council (2005). Double Diamond Design Process.

http://webarchive.nationalarchives.gov.uk/20080821115409/designcouncil.org.u k/en/about-design/managingdesign/the-study-of-the-design-process/

Design Council (2010). Design out Crime. URL:

http://www.designcouncil.org.uk/resources/case-study/design-out-crime.

Dorst, K. (2015). Frame innovation: Create New Thinking by Design. MIT Press. Ekblom, P. (2010). The conjunction of criminal opportunity theory. In:

Encyclopedia of Victimology and Crime Prevention. Sage, London, UK, pp. 140146

Ekblom, P. (2011). New thinking on crime prevention through environmental design. European Journal on Criminal Policy and Research, 17 (1). pp. 1-6. Ekblom, P. (Ed.) (2012). Design Against Crime: Crime Proofing Everyday Objects. Crime Prevention Studies 27 Boulder, Col.: Lynne Rienner.

Ekblom, P. and Gill, M. (2015) Rewriting the Script: Cross-Disciplinary Exploration and Conceptual Consolidation of the Procedural Analysis of Crime. European Journal on Criminal Policy and Research.

Felson, M. (1994). Crime and everyday life: Insight and implications for society. Thousand Oaks: Pine Forge Press.

Gamman, L. and Thorpe, A. (2011). Design with society: why socially responsive design is good enough, CoDesign International Journal of CoCreation in Design and the Arts, 7 (3-4), 217-231.

Gamman, L. and Thorpe, A. (2015). Could design help promote and build empathic processes in prison? Understanding the role of empathy and design in catalysing social change and transformation. In: J. Wolfgang (Ed.), Transformation Design. Basel, Switzerland: Birkhäuser / BIRD.

Gatsby, C. (2014). Social Architecture: A New Approach To Designing Social Spaces, Huffington Post, 06 May 2014. http://www.huffingtonpost.com/claudiagatsby/social-architecture-a-new_b_5448130.html [1 ${ }^{\text {st }}$ Aug 2015].

Halpern, D. (2015). Inside the Nudge Unit: how small changes can make a big difference. London: WH Allen.

Holt, T. and Spencer, J. (2005). 'A Little Yellow Box: The Targeting of Automatic Teller Machines as a Strategy in Reducing Street Robbery'. Crime Prevention and Community Safety: An International Journal, 7: 15-28.

House of Lords (2011). Behaviour Change Report, Science and Technology Select Committee, $2^{\text {nd }}$ Report of Sessions 2010-12. HL Paper 179.

Jacobs, J. (1961). The Death and Life of Great American Cities. New York: 
Random House.

Jeffrey, C. R. (1971). Crime Prevention Through Environmental Design. Beverly Hills, CA: Sage.

Kitchen, T. and Schenider, R. H. (2007). Crime Prevention and the Built Environment. Abingdon, Oxon: Routledge.

Knights, B., Pascoe, T. and Henchley, A. (2002). Sustainability and Crime:

Managing and Recognising the Drivers of Crime and Security Building Research Establishment: Garston, Watford, 2002.

Leadbeater, C. \& Powell, D. (2009). We-think. London: Profile Books.

Lockton, D., Harrison, D. J., and Stanton, N. A. (2010a). Design with intent: 101 patterns for influencing behaviour through design. Windsor, UK: Equifine.

Lockton, D., Harrison, D. J., \& Stanton, N. A. (2010b). The Design with Intent method: A design tool for influencing user behaviour. Applied Ergonomics, 41(3), 382-392.

Manzini, E. (2015). Design When Everybody Designs: An Introduction to Design for Social Innovation. Cambridge, Massachusetts: The MIT Press.

Murray, R., Caulier-Grice, J., and Mulgan, G. (2010). The open book of social innovation. National Endowment for Science, Technology and the Art.

Newman, O. (1972). Defensible space: crime prevention through urban design. New York, Macmillan.

Niedderer et al (2014). Creating sustainable innovation through design for behaviour change: full project report. University of Wolverhampton, Project Partners \& AHRC, 126.

Norman, D. A. (1988). The psychology of everyday things. New York: Basic Books.

Packard, V. (1957). The hidden persuaders. New York: D. McKay Co.

Papanek, V. (1995). The green imperative: ecology and ethics in design and architecture. London, Thames and Hudson.

Prime Minister's Office, Deputy Prime Minister's Office and Cabinet Office (2010). The Coalition: our programme for government. Crown.

Prison Reform Trust (2015). "Prison; the Facts", Bromley Briefing, Summer 2015

http://www.prisonreformtrust.org.uk/Portals/0/Documents/Prison\%20the\%20fact s\%20May\%202015.pdf.

Rittel, H. and Webber, M. (1973). Dilemmas in a General Theory of Planning. Policy Sciences, 4, 155-169.

Suchman L. A. (1987). Plans and situated actions: the problem of humanmachine communication. Cambridge: Cambridge University Press.

Thaler, R. H., and Sunstein, C. R. (2008). Nudge: improving decisions about health, wealth, and happiness. New Haven, Conn: Yale University Press. 
Thorpe, A., Gamman, L., Ekblom, P., Willcocks, M., Sidebottom, A. and Johnson, S.D. (2010). Bike Off 2 - Catalysing Anti Theft Bike, Bike Parking And Information Design For The 21st Century: An Open Research Approach. In: T. Inns (Ed.), Designing for the 21st Century. Volume 2: Interdisciplinary Methods and Findings, pp. 238-258. Farnham: Gower.

Thorpe, A., Johnson, S.D. and Sidebottom, A. (2012). The impact of seven prototype bicycle parking stands on opportunities for bicycle theft. In: P. Ekblom (Ed.) Designing out crime from products: Towards research-based practice. Crime Prevention Studies, Vol. 26. Monsey, NY: Criminal Justice Press.

Thorpe, A. (2013). ATM Art Evaluation Programme. London: Socially Responsive Design and Innovation Press.

Tromp, N., Hekkert, P. and Verbeek, P. (2011). Design for Socially Responsible Behavior: A Classification of Influence Based on Intended User Experience, Design Issues, 27 (3), 3-19.

Whitney, D. and Trosten-Bloom, A. (2010). The Power of Appreciative Inquiry (2nd Ed.). San Francisco: Berrett-Koehler.

Lorraine Gamman is Professor of Design at Central Saint Martins, at the University of the Arts, London, where in 1999 she founded the Design Against Crime Research Centre, which she continues to direct. She is also co-director of the Socially Responsive Design and Innovation Hub located there.

Adam Thorpe is Professor of Socially Responsive Design at Central Saint Martins College, University of the Arts London (UAL). He is Co Director of the Design Against Crime Research Centre and Director of the Socially Responsive Design Hub as well as Coordinator of the UAL DESIS Lab (Design for Social Innovation and Sustainability). 